KAWISTARA

VOLUME 7

No. 2, 22 Agustus 2017

Halaman 115-206

\title{
KOMPLEKSITAS PEMBAJAKAN KONTEN DI ERA DIGITAL
}

\section{Resensi}

(C) (C) (C) (C) (C) (C) (C) (C) (C) (C) (C)

(C) $\&$ (C) (C) (C) (C) (C) (C) (C) (C) (C)

(C) (C) (C) (C) (C) (C) (C) (C) (C) (C) (C)

\section{Piracy}

(C) Eategin (C) (C) (C) (C) (C) JAMES ARVANITAKIS (C) (C) (C) (C) (C) (C) (C) (C) (C) (C) (C) (C) (C) (C) (C) (C) (C) (C) (C) (C) (C) (C) (C) 2 (C) (C) (C) (C) (C) (C) (C) (C) (C) (C) (C) (C) (C) (C) (C) 2 (C) (C) (C) (C) (C) (C) (C) (C) (C) (C) (C) (C) (C) (C) (C) (C) (C) (C) (C) (C) (C) (C) (C) (C) (C) (C) (C) (C) (C) (C) (C) (C) (C) (c) (C) (C) (C) (C) (C) (C) (C)

\author{
Judul Buku : Piracy: Leakages from Modernity \\ Editor : Martin Fredriksson dan James Arvanitakis \\ Penerbit : Litwin Books, LLC \\ Halaman : 370 halaman \\ ISSBN : :978-1-936117-59-8 \\ Resensi : Tangguh Okta Wibowo
}

Sebuah buku menarik yang rilis di tahun 2014 untuk membicarakan isu yang sensitif yaitu pembajakan (piracy) di budaya kontemporer yang diasosiasikan dengan budaya berbagi (file sharing/ peer-to-peer) di dunia digital sekarang ini. Konsep umumnya adalah bagaimana seseorang 'bersembunyi' di balik layar komputer untuk mengunduh, baik musik, film, atau file digital lain, melintasi batas geografis secara anonimous atau melakukan hacking sebuah sistem komputer.
Buku ini terdiri dari beberapa artikel penelitian dengan sebuah tema besar pembajakan. Tidak hanya itu, tema besar ini pun dibagi menjadi tiga bagian spesifik, yaitu ontologi, politik, dan praktik terkait pembajakan. Hal ini memudahkan bagi pembaca untuk mengikuti kumpulan artikel ini dalam sebuah kerangka besar pembajakan yang digambarkan melalui sebuah sisi lain dari modernitas.

Buku ini terbagi menjadi tiga tema. Pertama yaitu perilaku pembajakan ini tidak hadir begitu saja/taken for granted. Kedua, politik dari pembajakan dari perspektif makro, dan menganalisis bagaimana privasi menghubungkan struktur kekuasaan dan proses transformasi. Terakhir, membahas beberapa praktik pembajakan dan implikasi dari beragam konteks pembajakan.

Bagian pertama adalah ontologi. Bagian pertama ini mendiskusikan beragam wacana terkait pembajakan yang seringkali diposisikan sebagai kriminal, pemberontakan, atau pengguna media biasa. Seharusnya kita tidak mendikotominya sebagai tindakan 'kriminal' atau 'pahlawan'. Rezim properti intelektual berubah dari pengetahuan menjadi komoditas dieksploitasi, dengan kata lain dijual untuk keuntungan. Hal ini memperkuat bagaimana pembajakan dapat dikonseptualisasikan sebagai wacana tandingan yang bertujuan untuk menyingkap industri hiburan menggunakan hak kekayaan intelektual untuk 'membajak' sumberdaya yang sebelumnya milik bersama.

Bagian kedua adalah aspek politik. Pembajakan melibatkan struktur sosial dan politik dari masyarakat modern. Pembajakan di dunia digital ini seringkali dianggap sebelah mata sebagai kekerasan dan sebaiknya dihentikan secara paksa. Bagaimana buku ini menggambarkan dua sisi, tidak hanya pada sisi kekerasan yang merampas rezim properti privat, tetapi buku ini juga mengajak pembaca dalam melihat potensi berbagi file di dunia 
digital, yaitu melihat potensi teknologi yang demokratis dan dapat menjangkau semua lapisan penggunanya. Buku ini juga mengajak lebih jauh untuk mempertanyakan konsep rezim hak cipta yang sebaiknya direvisi untuk mengikuti perkembangan teknologi sekarang ini.

Tema terakhir dalam buku ini adalah beragam praktik terkait pembajakan. Pada bagian ini, penulis menghadirkan beberapa kasus terkait praktik pembajakan dengan analisis yang mendalam. Praktik berbagi file berhakcipta seringkali dilakukan menggunakan sebuah platform, seperti platform mainstream melalui website The Pirate Bay. Praktik berbagi file ini tidak lepas dari norma dan pengaturnya, kadang juga tidak selalu gratis. Misalnya, sebelum pengguna mengunduh sebuah konten, ia harus berkontribusi mengupload beberapa material juga kepada komunitas. Poin di sini adalah pemegang hak cipta sebaiknya dapat diberikan kredit untuk membolehkan karyanya di sini. Praktik pembajakan ini menolak untuk mengakui batasan-batasan politik, sosial, fisik, atau lainnya karena semua dilakukan secara digital.

Contoh kasus lain, melalui buku ini pembaca dapat belajar dari sebuah kasus TV show di Brazil yang membuka peluang bagi sukarelawan yang ingin menampilkan teks terjemahan (subtitle) untuk film yang ditayangkan. Bagi penulis subtitle (fansubbing), mereka tidak mengharapkan pembayaran uang. Semua ini dilakukan dengan sukarela, tidak seperti pengalih bahasa profesional yang dibayar oleh stasiun TV dengan mahal. Akan tetapi, karya dari funsubbing ini hanya mendapatkan sebuah pengakuan dan apresiasi dari komunitas file-sharing yang mengganti gratifikasi finansial/materi sebagai insentif dan reward bagi pekerjaan yang tidak dibayar. Praktik kolaboratif dari budaya berbagi file dalam beberapa kasus memenuhi tujuan dari industri media, misalnya kasus fansubbing ini dapat dilihat sebagai tenaga kerja yang tidak dibayar dalam mempromosikan film Amerika di luar negeri untuk enak ditonton dengan subtitle bahasa lokal tanpa harus membayar pengalih bahasa profesional.
Buku ini mengemas fenomena pembajakan menjadi menarik karena pembaca tidak hanya diarahkan pada satu sisi yang menganggap bahwa pembajakan selalu salah. Akan tetapi, buku ini juga mengajak potensi yang dilahirkan. Buku ini tidak menawarkan posisi konsisten terhadap pembajakan karena pembajakan ini merupakan sebuah konsep ambigu. Pembajakan ini juga mengikuti perkembangan internet yang bersifat sementara. Jadi keadaan ini memerlukan proses pembelajaran dan eksplorasi yang lebih kompleks lagi di masa depan.

Buku ini mengajak pembaca untuk memahami lebih jauh terkait pembajakan, yaitu bagaimana menghentikan praktik ini atau bagaimana seniman, produser, dan pemegang hak cipta mendapatkan kompensasi jika mereka menerima kondisi yang saat ini secara bebas praktik berbagi file di era digital ini. Ketika menyalin konten secara ilegal sudah merajalela pada saat awal ditemukannya mesin cetak, dan kondisi ini menjadi sangat kompleks di era digital karena konten dapat direproduksi tidak terbatas. Buku ini juga membuka pandangan terbuka bahwa pembajakan juga dapat dipahami sebagai mimpi untuk masa depan dalam memperjuangkan sumberdaya yang meleburkan batas privat dan publik, perjuangan di antara batas perpotongan properti dan milik bersama atau kolektif.

Buku ini sangat cocok bagi kaum akademisi untuk memperdalam dan membuka khazanah pengetahuan tentang pembajakan dan tidak menghakimi secara sepihak. Untuk itu, buku ini menghadirkan beragam perspektif, dari bermacam-macam kasus terkait pembajakan, dan dikelompokkan berdasarkan tiga tema yang mempermudah menyeleksi pembacaan sehingga pengetahuan mengenai pembajakan di dunia digital akan semakin berkembang dan semakin kompleks untuk melihat permasalahan pembajakan di era digital. 